\title{
Parallel Ionic Liquid Semi-Packed Microfabricated Columns for Complex Gas Analysis
}

\author{
Azam Gholizadeh, Mustahsin Chowdhury, Masoud Agah*
}

VT MEMS Lab, Bradley Department of Electrical and Computer Engineering, Virginia Tech, Blacksburg, VA, 24061, United States

\section{Email: agah@vt.edu}

\section{Table of Content}

Fabrication steps of micro-packed columns 4

C7-C30 alkanes sample analysis 5

$\begin{array}{ll}\text { Classification of the stationary phases } & 7\end{array}$

2D plots of the chromatograms 9

Thickness calculation of the IL stationary phases 13

$\begin{array}{ll}\text { References } & 16\end{array}$ 


\section{List of Figures}

Figure S1: Chromatograms showing the separation of saturated alkanes C7-C30 using (A) $[\mathrm{BPY}]\left[\mathrm{NTf}_{2}\right],(\mathrm{B})[\mathrm{HOEMIM}]\left[\mathrm{NTf}_{2}\right],(\mathrm{C})[\mathrm{N} 1888]\left[\mathrm{NTf}_{2}\right]$ based stationary phases. Condition: injection volume $0.3 \mu \mathrm{l}$, split ratio 200:1, carrier gas pressure $20 \mathrm{psi}$, initial oven temperature $30{ }^{\circ} \mathrm{C}$; ramp rate $100{ }^{\circ} \mathrm{C} / \mathrm{min}$ to $200{ }^{\circ} \mathrm{C}$ and held for $2 \mathrm{~min}$. (for (C) held for $8 \mathrm{~min})$. The retention time of the chemicals is listed in Table S2 ......................4

Figure S2: Chromatograms showing the separation of a 20 component mixture of organic compounds using (A) [BPY][NTf $\left.{ }_{2}\right]$, (B) [HOEMIM] $\left[\mathrm{NTf}_{2}\right]$, and (C) [N1888][NTf $\left.{ }_{2}\right]$ stationary phases. Condition: injection volume $0.3 \mu \mathrm{l}$, split ratio 200:1, carrier gas pressure $20 \mathrm{psi}$, initial oven temperature $30^{\circ} \mathrm{C}$; ramp rate $100{ }^{\circ} \mathrm{C} / \mathrm{min}$ to $200{ }^{\circ} \mathrm{C}$ and held for $2 \mathrm{~min}$. The retention time of the chemicals is listed in Table $\mathrm{S} 2$.

Figure S3: Chromatograms showing the separation of a five component mixture of polar standard chemicals using (A) [BPY] $\left[\mathrm{NTf}_{2}\right],(\mathrm{B})$ [HOEMIM] $\left[\mathrm{NTf}_{2}\right],(\mathrm{C})$ [N1888][NTf $\left.{ }_{2}\right]$ based stationary phases. Condition: injection volume $0.3 \mu \mathrm{l}$, split ratio 200:1, carrier gas pressure $20 \mathrm{psi}$, initial oven temperature $30^{\circ} \mathrm{C}$; ramp rate $100{ }^{\circ} \mathrm{C} / \mathrm{min}$ to $200{ }^{\circ} \mathrm{C}$ and held for $2 \mathrm{~min}$. The retention time of the chemicals is listed in Table S2

Figure S4: Chromatogram and Kovats retention index plot for $\mathrm{C} 7-\mathrm{C} 20$ saturated alkanes mixture for (A) [BPY][NTf 2 , (B) $[\mathrm{HOEMIM}]\left[\mathrm{NTf}_{2}\right]$, (C) $[\mathrm{N} 1888]\left[\mathrm{NTf}_{2}\right]$ ionic liquids stationary phases. Separation conditions: injection volume $0.3 \mu$, split ratio 200:1, carrier gas pressure $20 \mathrm{psi}$, oven temperature: $150^{\circ} \mathrm{C}$.

Figure S5: Chromatograms showing the separation of a 46-components mixture of organic compounds using (A) [BPY] $\left[\mathrm{NTf}_{2}\right]$, (B) [HOEMIM] $\left[\mathrm{NTf}_{2}\right],(\mathrm{C})$ [N1888][NTf $\left.{ }_{2}\right]$ based stationary phases. Condition: injection volume $0.3 \mu$, split ratio 200:1, carrier gas pressure $20 \mathrm{psi}$, initial oven temperature $30{ }^{\circ} \mathrm{C}$; ramp rate $100{ }^{\circ} \mathrm{C} / \mathrm{min}$ to $200{ }^{\circ} \mathrm{C}$ and held for $2 \mathrm{~min}$. The retention time of the chemicals is listed in Table S2. ..8

Figure S6: 3D chromatograms of the $[\mathrm{BPY}]\left[\mathrm{NTf}_{2}\right]$ and $[\mathrm{N} 1888]\left[\mathrm{NTf}_{2}\right]$ ionic liquids. $(A, B)$ show surface and contour plots for the range of 0.2 to 0.4 min retention time, $(C, D)$ show surface and contour plots for the range of 0.4 to 0.6 min retention time. 


\section{List of Tables}

Table S1: Chemical list and their retention regarding different ionic liquids for the ramp

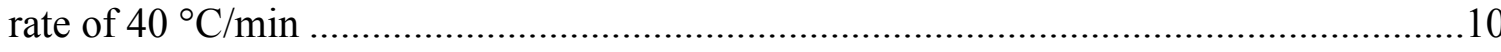

Table S2: Chemical list and their retention regarding different ionic liquids for the ramp

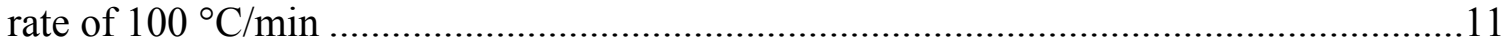

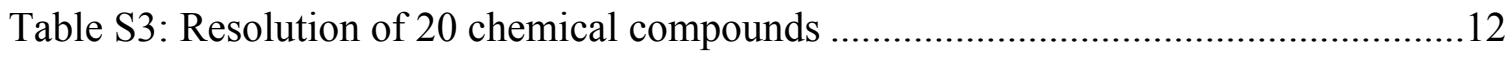

Table S4: Isothermal retention times of polar probes................................................. 12

Table S5: Selectivity Index of ionic liquids stationary phases...................................13

Table S6: parameters for IL thickness calculation. ................................................ 14

Table S7: Part catalog number of chemicals. ............................................................. 15 
Fabrication steps of micro-packed columns. First, the silicon wafer was coated with AZ 9260 photoresist. Then, the photoresist was exposed and developed using AZ 400K developer. Silicon pillars were created by deep reactive ion etching (DRIE) process (Alcatel AMS 100). Sulfur hexafluoride $\left(\mathrm{SF}_{6}\right)$ was used as an etchant and octafluorocyclobutane $\left(\mathrm{C}_{4} \mathrm{~F}_{8}\right)$ served as a passivation precursor. The pillars were designed to be $20 \mu \mathrm{m}$ in diameter. SEM images revealed that they were $16 \mu \mathrm{m}$ in diameter due to lateral etching. The height of pillars was measured to be about $240 \mu \mathrm{m}$. The photoresist was removed by treating the wafer with acetone and oxygen plasma, consequently. The layer of alumina was deposited via atomic layer deposition using trimethylaluminium and water as precursors by employing the procedure described elsewhere. ${ }^{1}$ The thickness of the alumina layer was measured to be $13 \mathrm{~nm}$ using woollam ellipsometer (J.A. Woollam, Lincoln, NE, US). The etched silicon wafer was anodically bonded with a $175 \mu \mathrm{m}$ thick Borofloat glass wafer at $1250 \mathrm{~V}$ and $400{ }^{\circ} \mathrm{C}$. Finally, the wafer was diced into individual devices. To avoid entering the water during dicing, this step was divided into two partially dicing from back and front.

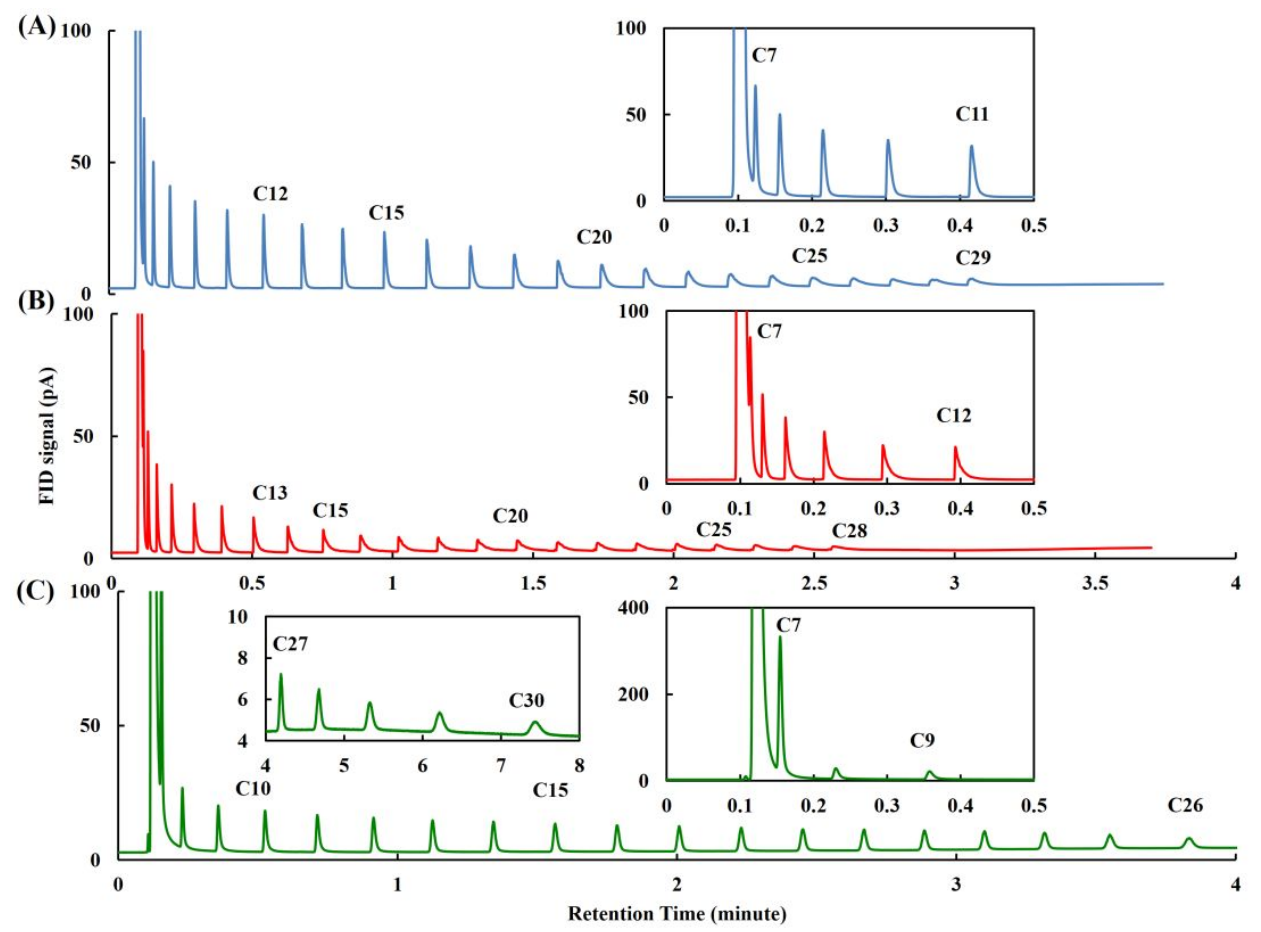

Figure S1: Chromatograms showing the separation of saturated alkanes C7-C30 using (A) [BPY] $\left[\mathrm{NTf}_{2}\right]$, (B) $[\mathrm{HOEMIM}]\left[\mathrm{NTf}_{2}\right]$, (C) $[\mathrm{N} 1888]\left[\mathrm{NTf}_{2}\right]$ based stationary phases. Condition: injection volume $0.3 \mu$ l, split ratio $200: 1$, carrier gas pressure $20 \mathrm{psi}$, initial oven temperature 30 ${ }^{\circ} \mathrm{C}$; ramp rate $100{ }^{\circ} \mathrm{C} / \mathrm{min}$ to $200{ }^{\circ} \mathrm{C}$ and held for $2 \mathrm{~min}$. (for (C) held for $8 \mathrm{~min}$ ). The retention time of the chemicals is listed in Table S2. 
C7-C30 alkanes sample analysis. IL1 column was able to separate C7 to C29 (C30 was undetectable) in $180 \mathrm{~s}$ with a ramp rate of $100{ }^{\circ} \mathrm{C} / \mathrm{min}$ from $30{ }^{\circ} \mathrm{C}$ to $200{ }^{\circ} \mathrm{C}$ and then kept for 2 minute (Figure S1A). With the same temperature condition, IL2 column was able to separate $\mathrm{C} 7$ to $\mathrm{C} 28$ in $177 \mathrm{~s}$ (C29 and C30 were undetectable) (Figure S1B). IL3 separated $\mathrm{C} 7$ to $\mathrm{C} 30$ in $460 \mathrm{~s}$ with the same ramp rate but for this one, the temperature was kept at $200{ }^{\circ} \mathrm{C}$ for $8 \mathrm{~min}$ (Figure S1C).

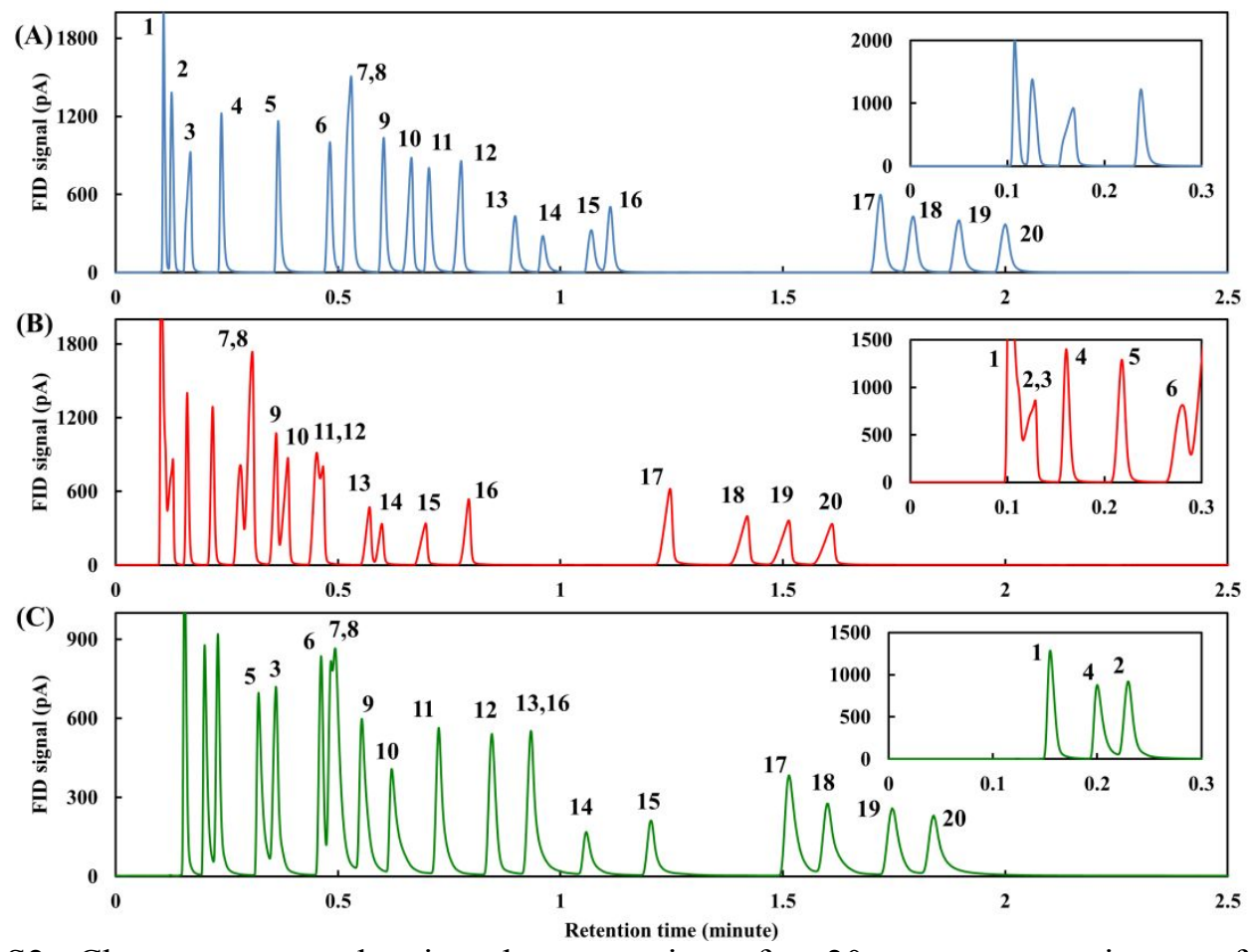

Figure S2: Chromatograms showing the separation of a 20 component mixture of organic compounds using (A) [BPY] $\left[\mathrm{NTf}_{2}\right]$, (B) [HOEMIM] $\left[\mathrm{NTf}_{2}\right]$, and (C) $[\mathrm{N} 1888]\left[\mathrm{NTf}_{2}\right]$ stationary phases. Condition: injection volume $0.3 \mu$, split ratio 200:1, carrier gas pressure $20 \mathrm{psi}$, initial oven temperature $30{ }^{\circ} \mathrm{C}$; ramp rate $100{ }^{\circ} \mathrm{C} / \mathrm{min}$ to $200{ }^{\circ} \mathrm{C}$ and held for $2 \mathrm{~min}$. The retention time of the chemicals is listed in Table S2. 

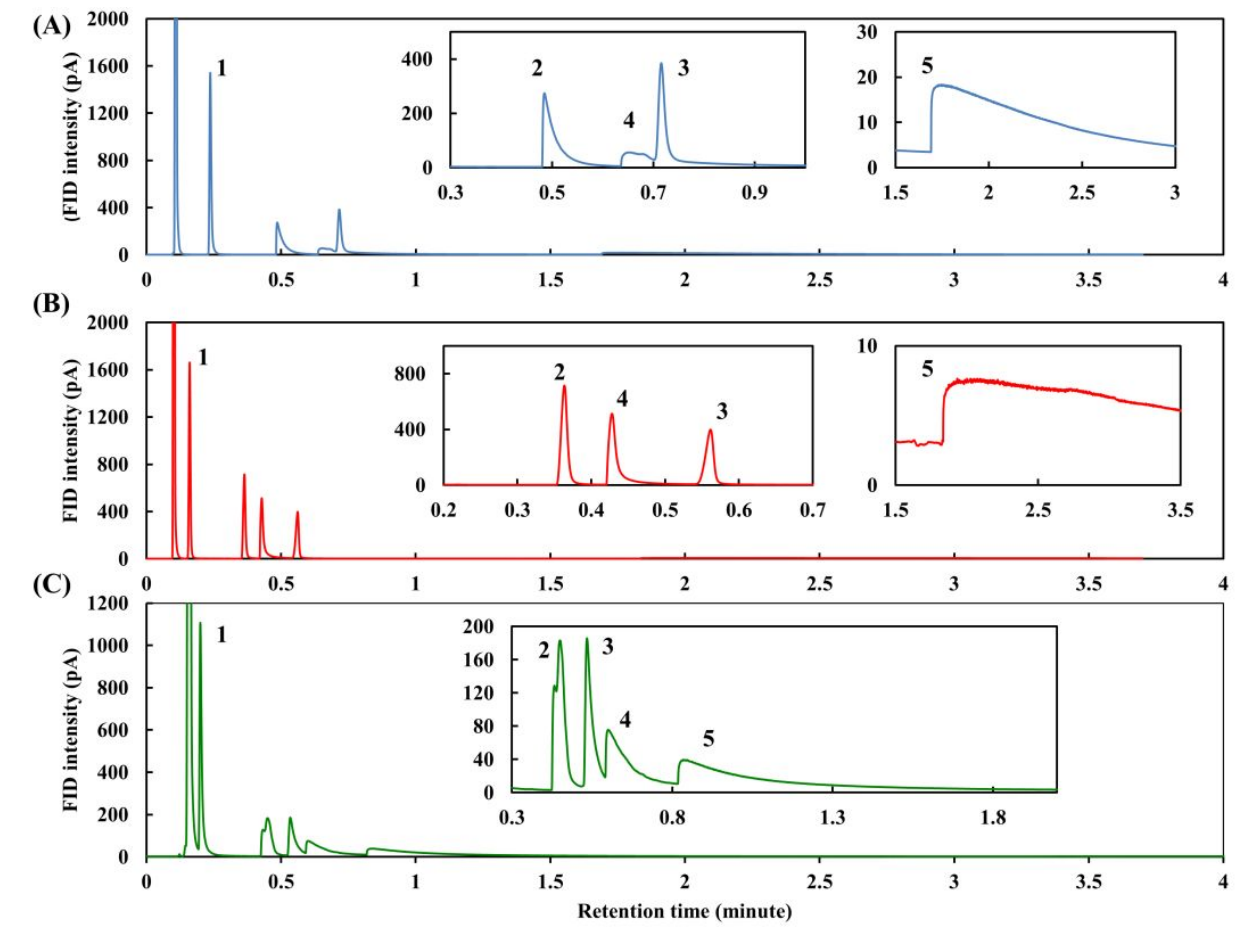

Figure S3: Chromatograms showing the separation of a five component mixture of polar standard chemicals using (A) [BPY] $\left[\mathrm{NTf}_{2}\right]$, (B) [HOEMIM] $\left[\mathrm{NTf}_{2}\right]$, (C) [N1888][NTf $\left.{ }_{2}\right]$ based stationary phases. Condition: injection volume $0.3 \mu$, split ratio $200: 1$, carrier gas pressure $20 \mathrm{psi}$, initial oven temperature $30{ }^{\circ} \mathrm{C}$; ramp rate $100{ }^{\circ} \mathrm{C} / \mathrm{min}$ to $200{ }^{\circ} \mathrm{C}$ and held for $2 \mathrm{~min}$. The retention time of the chemicals is listed in Table S2. 

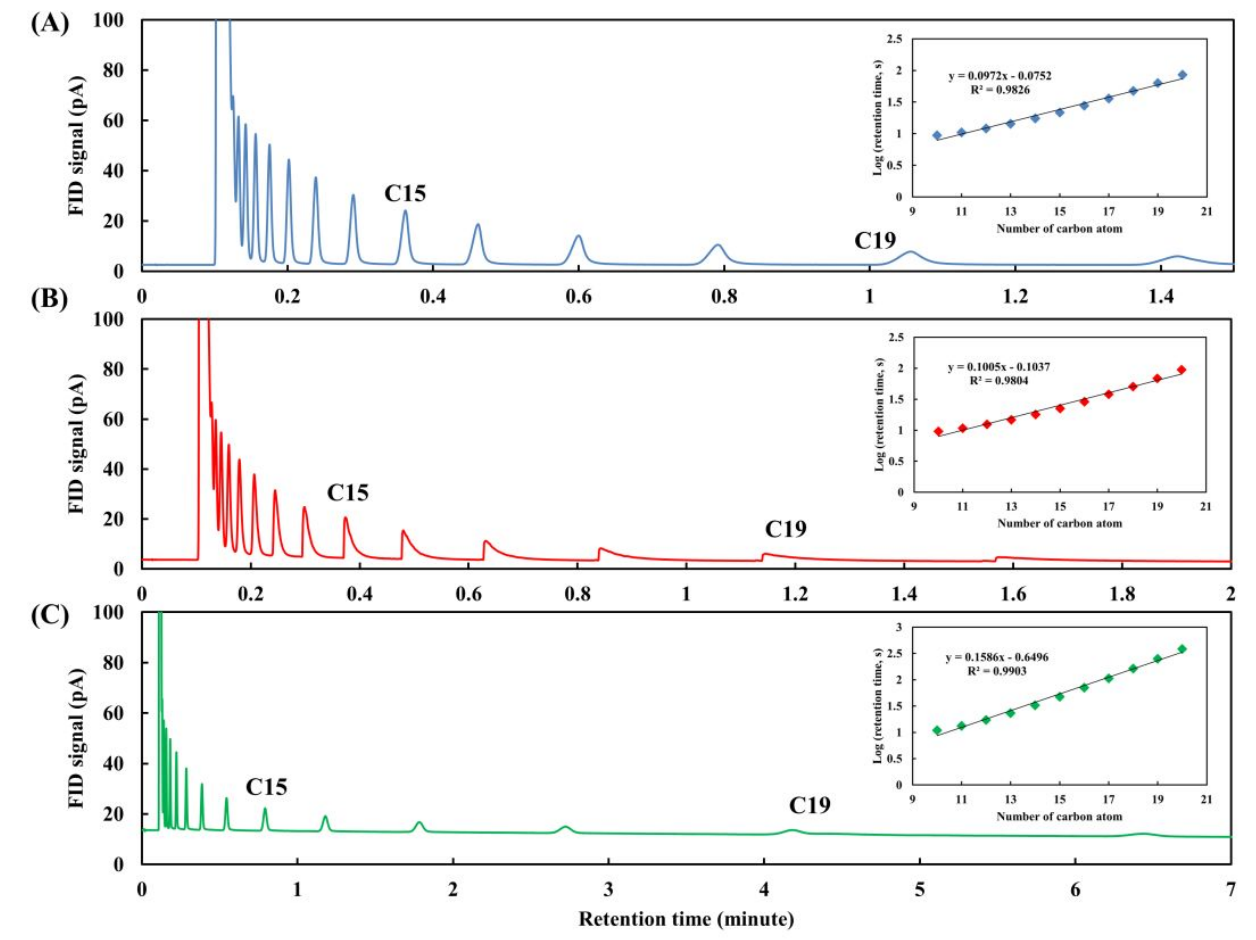

Figure S4: Chromatogram and Kovats retention index plot for $\mathrm{C} 7-\mathrm{C} 20$ saturated alkanes mixture for (A) [BPY] $\left[\mathrm{NTf}_{2}\right],(\mathrm{B})[\mathrm{HOEMIM}]\left[\mathrm{NTf}_{2}\right],(\mathrm{C})[\mathrm{N} 1888]\left[\mathrm{NTf}_{2}\right]$ ionic liquids stationary phases. Separation conditions: injection volume $0.3 \mu \mathrm{l}$, split ratio $200: 1$, carrier gas pressure $20 \mathrm{psi}$, oven temperature: $150^{\circ} \mathrm{C}$.

Classification of the stationary phases. To compare the relative polarity of the ILs, the selectivity index was applied. It defines as equation $\mathrm{I}=\mathrm{I}_{\mathrm{M}}+\mathrm{I}^{*}$, where $\mathrm{I}_{\mathrm{M}}$, the dispersion index, is the retention index of n-alkane having the same molecular weight, $M$, with probe molecular and $I^{*}$ is the selectivity index ${ }^{2}$. Selectivity index includes the effect of molecular shape and functionality in the retention index. Besides, it changes with the molecular structure of the stationary phase. For a specific molecular probe, I* increases with the presence of more polar functional groups into the phase. Particularly, these effects are greater for the molecular probes having proton donor acceptor properties. Benzene, butanol, pentanone, nitropropane, and pyridine were used as the probe molecules representing different molecular interactions. The benzene was utilized to evaluate pi-type (aromatic), butanol for electron attracting effect (alcohols, nitriles, acids, nitro and chloro compounds), pentanone for dipole-dipole (ketones, aldehydes, ethers, epoxides, amino), nitropropane for electron donating effect (nitro, nitrile), and pyridine for non-bonding electron attraction (bases), $\mathrm{H}$ bonding capability ${ }^{3,4}$. The kovats retention 
index of each probe molecule for each stationary phase was calculated using isothermal chromatogram results. These data were achieved based on saturated alkane separation analysis (figure S4, Table S4). The result of the selectivity index calculation is shown in Table S5. IL1 demonstrates the highest selectivity index that is similar to the reported amount for the PEG 4000 stationary phase. IL3 shows the lowest amount similar to the squalene stationary phase.
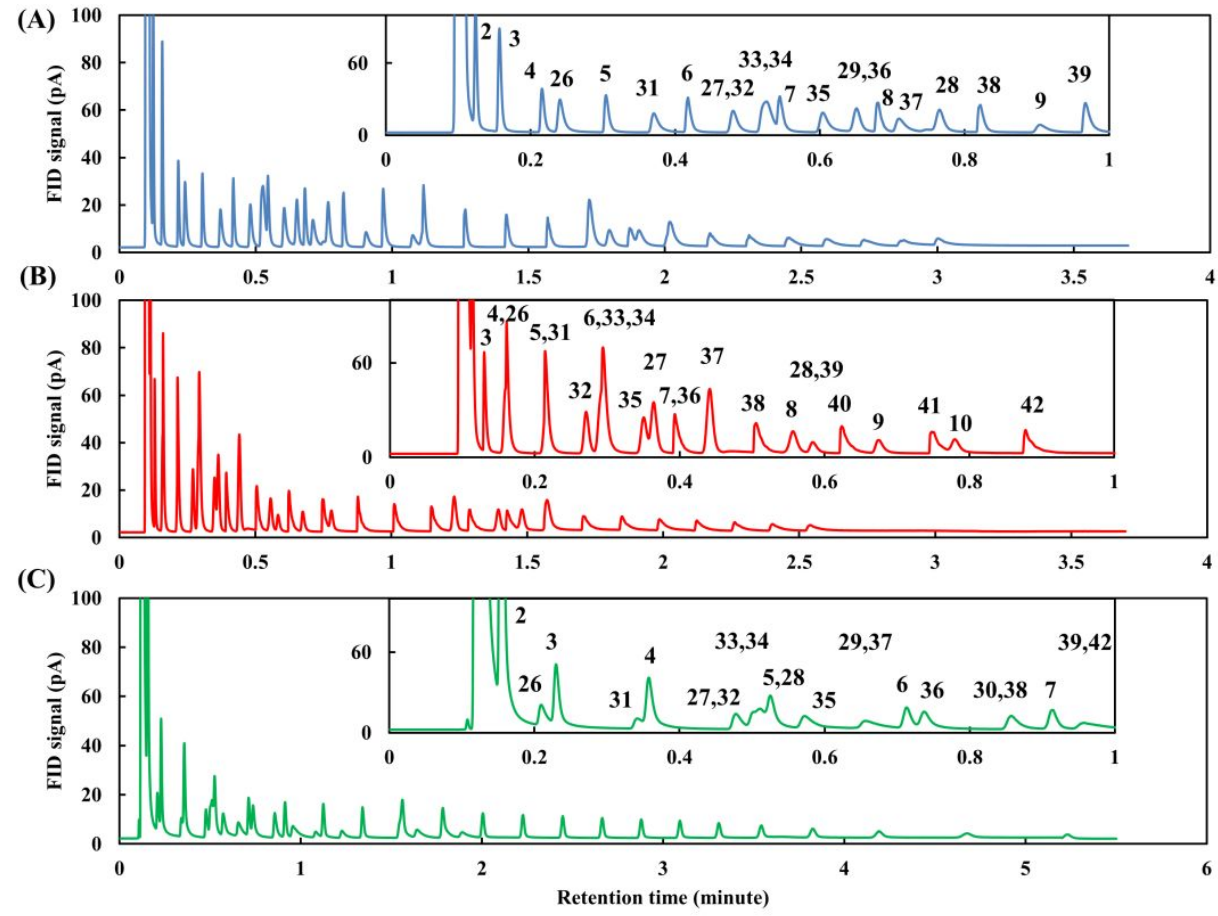

Figure S5: Chromatograms showing the separation of a 46-components mixture of organic compounds using (A) [BPY][NTf 2 , (B) [HOEMIM] $\left[\mathrm{NTf}_{2}\right],(\mathrm{C})$ [N1888][ $\left.\mathrm{NTf}_{2}\right]$ based stationary phases. Condition: injection volume $0.3 \mu \mathrm{l}$, split ratio 200:1, carrier gas pressure $20 \mathrm{psi}$, initial oven temperature $30{ }^{\circ} \mathrm{C}$; ramp rate $100{ }^{\circ} \mathrm{C} / \mathrm{min}$ to $200{ }^{\circ} \mathrm{C}$ and held for $2 \mathrm{~min}$. The retention time of the chemicals is listed in Table S2. 

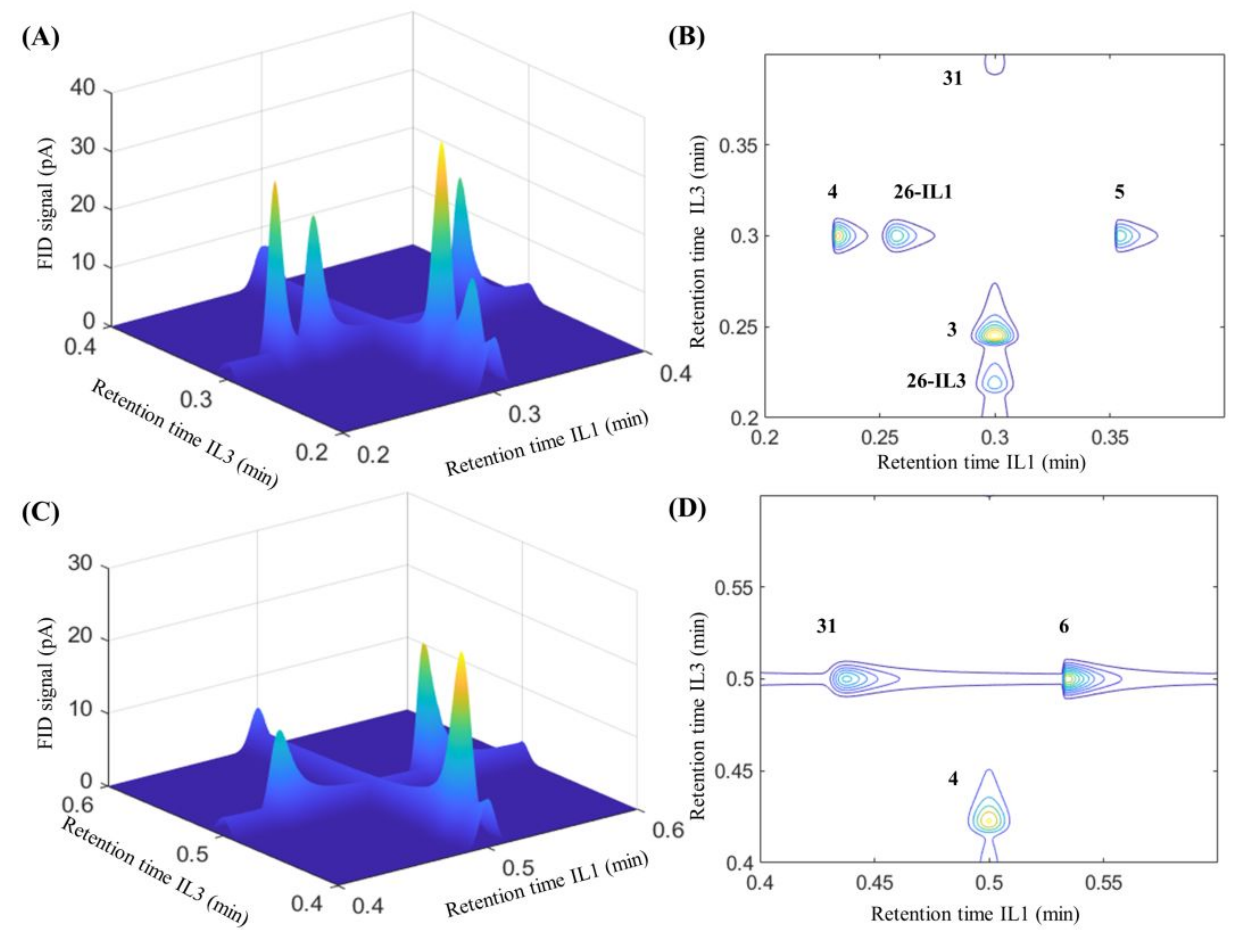

Figure S6: 3D chromatograms of the $[\mathrm{BPY}]\left[\mathrm{NTf}_{2}\right]$ and $[\mathrm{N} 1888]\left[\mathrm{NTf}_{2}\right]$ ionic liquids. $(\mathrm{A}, \mathrm{B})$ show surface and contour plots for the range of 0.2 to 0.4 min retention time, $(C, D)$ show surface and contour plots for the range of 0.4 to 0.6 min retention time.

2D plots of the chromatograms. Figure S6 A, B show surface and contour 2D plots from 12 to 24 seconds of IL1 and IL3 chromatograms. This can be another way to represent the parallel configuration columns data. This sort of interpretation gives opportunity to have more data in a specific period of the separation time. To indicate the concept, the very short time shots were selected but this is applicable also for the whole chromatogram. The chromatograms of two different stationary phases (IL1 and IL3) rotated 90 degrees and centralized with respect to each other to show simultaneously all possible peaks. Represented 2D plots provide more information in the same period of time. For example, for benzene (26), two indicators are identified and in the period of 12 seconds in addition of retention time for nonane (4), benzene (26) and C10 (5), the data for octane (3) and toluene (31) were appeared because of the different polarity of IL3 in comparison to IL1. Figure S6C, D show, respectively, surface and contour plots from 24 to 36 seconds for IL1 and IL3 chromatograms. In addition to toluene (31), nonane (4) also appeared because of IL3 based column. 
Table S1: Chemical list and their retention regarding different ionic liquids for the ramp rate of 40 ${ }^{\circ} \mathrm{C} / \mathrm{min}$

\begin{tabular}{|c|c|c|c|c|c|c|c|c|}
\hline Peak & Peak & Compounds & [BPY] & [BPY] & [HOEMIM] & [HOEMIM] & [N1888] & [N1888] \\
\hline number in & number in & & $t_{R}(\min )$ & $t_{R}(\min )$ & $t_{R}(\min )$ & $\mathrm{t}_{\mathrm{R}}(\min )$ & $t_{R}(\min )$ & $t_{R}(\min )$ \\
\hline Mixture & Individual & & Mixture & Individual & Mixture & Individual & Mixture & Individual \\
\hline 1 & 1 & C6 & 0.098 & 0.097 & 0.980 & 0.097 & 0.121 & 0.122 \\
\hline 2 & 2 & $\mathrm{C} 7$ & 0.123 & 0.123 & 0.113 & 0.114 & 0.157 & 0.157 \\
\hline 3 & 3 & C8 & 0.160 & 0.158 & 0.134 & 0.131 & 0.245 & 0.247 \\
\hline 4 & 4 & C9 & 0.233 & 0.227 & 0.169 & 0.169 & 0.423 & 0.426 \\
\hline 5 & 5 & C10 & 0.356 & 0.347 & 0.239 & 0.237 & 0.700 & 0.702 \\
\hline 6 & 6 & C11 & 0.536 & 0.525 & 0.360 & 0.354 & 1.052 & 1.032 \\
\hline 7 & 7 & C12 & 0.759 & 0.747 & 0.530 & 0.522 & 1.373 & 1.372 \\
\hline 8 & 8 & C13 & 1.002 & 0.99 & 0.728 & 0.726 & 1.706 & 1.706 \\
\hline 9 & 9 & C14 & 1.248 & 1.237 & 0.952 & 0.947 & 2.026 & 2.025 \\
\hline 10 & 10 & C15 & 1.489 & 1.48 & 1.171 & 1.171 & 2.330 & 2.330 \\
\hline 11 & 11 & C16 & 1.720 & 1.713 & 1.389 & 1.391 & 2.622 & 2.621 \\
\hline 12 & 12 & $\mathrm{C} 17$ & 1.943 & 1.936 & 1.602 & 1.604 & 2.902 & 2.900 \\
\hline 13 & 13 & C18 & 2.157 & 2.151 & 1.803 & 1.810 & 3.168 & 3.167 \\
\hline 14 & 14 & C19 & 2.362 & 2.358 & 2.007 & 2.007 & 3.423 & 3.421 \\
\hline 15 & 15 & $\mathrm{C} 20$ & 2.559 & 2.556 & 2.179 & 2.201 & 3.667 & 3.665 \\
\hline 16 & 16 & $\mathrm{C} 21$ & 2.747 & 2.747 & 2.383 & 2.386 & 3.901 & 3.900 \\
\hline 17 & 17 & $\mathrm{C} 22$ & 2.929 & 2.931 & 2.564 & 2.566 & 4.126 & 4.124 \\
\hline 18 & 18 & $\mathrm{C} 23$ & 3.104 & 3.106 & 2.736 & 2.741 & 4.344 & 4.341 \\
\hline 19 & 19 & $\mathrm{C} 24$ & 3.272 & 3.276 & 2.905 & 2.909 & 4.579 & 4.576 \\
\hline 20 & 20 & $\mathrm{C} 25$ & 2.434 & 3.438 & 3.070 & 3.070 & 4.864 & 4.861 \\
\hline 21 & 21 & $\mathrm{C} 26$ & 3.592 & 3.596 & 3.229 & 3.227 & 5.230 & 5.228 \\
\hline 22 & 22 & $\mathrm{C} 27$ & 3.744 & 3.751 & 3.388 & 3.389 & 5.718 & 5.714 \\
\hline 23 & 23 & $\mathrm{C} 28$ & 3.892 & 3.898 & 3.539 & 3.540 & 6.369 & 6.369 \\
\hline 24 & 24 & $\mathrm{C} 29$ & 4.033 & 4.042 & - & - & 7.250 & 7.263 \\
\hline 25 & 25 & C30 & - & - & - & - & - & - \\
\hline 26 & 1 & Benzene & 0.257 & 0.251 & 0.162 & 0.1603 & 0.219 & 0.208 \\
\hline 27 & 2 & Pentanone & 0.612 & 0.623 & 0.437 & 0.426 & 0.607 & 0.552 \\
\hline 28 & 3 & Nitropropane & 1.002 & 0.989 & 0.740 & 0.734 & 0.700 & 0.693 \\
\hline 29 & 4 & Butanol & 1.058 & 0.933 & 0.548 & 0.534 & 0.919 & 0.866 \\
\hline 30 & 5 & Pyridine & 2.599 & 2.600 & 2.736 & 2.700 & 1.259 & 1.277 \\
\hline- & 1 & Heptane & - & 0.108 & - & 0.102 & - & 0.157 \\
\hline- & 2 & Octane & - & 0.126 & - & 0.126 & - & 0.243 \\
\hline- & 3 & Nonane & - & 0.169 & - & 0.163 & - & 0.424 \\
\hline- & 4 & Benzene & - & 0.253 & - & 0.163 & - & 0.207 \\
\hline 31 & 5 & Toluene & 0.438 & 0.428 & 0.227 & 0.229 & 0.396 & 0.36 \\
\hline 32 & 6 & Ethylbenzene & 0.612 & 0.610 & 0.299 & 0.310 & 0.607 & 0.577 \\
\hline 33 & 7 & P-Xylene & 0.691 & 0.691 & 0.330 & 0.346 & 0.640 & 0.614 \\
\hline 34 & 8 & m-Xylene & 0.691 & 0.691 & 0.330 & 0.346 & 0.664 & 0.631 \\
\hline 35 & 9 & o-Xylene & 0.823 & 0.814 & 0.413 & 0.424 & 0.767 & 0.731 \\
\hline 36 & 10 & Isobutylbenzene & 0.908 & 0.925 & 0.437 & 0.466 & 1.031 & 1.032 \\
\hline 37 & 11 & Styrene & 1.002 & 0.983 & 0.560 & 0.562 & 0.919 & 0.846 \\
\hline 38 & 12 & Butylbenzene & 1.106 & 1.118 & 0.560 & 0.595 & 1.259 & 1.237 \\
\hline 39 & 13 & 1,2-Dichlorobenzene & 1.319 & 1.299 & 0.740 & 0.760 & 1.406 & 1.365 \\
\hline 40 & 14 & 2,5-Dichlorotoluene & 1.439 & 1.411 & 0.796 & 0.814 & 1.616 & 1.572 \\
\hline 41 & 15 & 1,2,4-Trichlorobenzene & 1.602 & 1.580 & 1.126 & 0.982 & 1.833 & 1.791 \\
\hline 42 & 16 & Benzyl chloride & 1.647 & 1.641 & 1.126 & 1.145 & 1.406 & 1.365 \\
\hline 43 & 17 & Naphthalene & 2.504 & 2.493 & 1.830 & 1.848 & 2.279 & 2.229 \\
\hline 44 & 18 & 2-Nitrotoluene & 2.599 & 2.588 & 2.060 & 2.092 & 2.410 & 2.347 \\
\hline 45 & 19 & 3-Nitrotoluene & 2.73 & 2.718 & 2.195 & 2.219 & 2.593 & 2.539 \\
\hline 46 & 20 & 4-Nitrotoluene & 2.871 & 2.848 & 2.307 & 2.348 & 2.730 & 2.659 \\
\hline
\end{tabular}


Table S2: Chemical list and their retention regarding different ionic liquids for the ramp rate of $100{ }^{\circ} \mathrm{C} / \mathrm{min}$

\begin{tabular}{|c|c|c|c|c|c|c|c|c|}
\hline $\begin{array}{l}\text { Peak } \\
\text { number in } \\
\text { Mixture }\end{array}$ & $\begin{array}{c}\text { Peak } \\
\text { number in } \\
\text { Individual }\end{array}$ & Compounds & $\begin{array}{c}{[\mathrm{BPY}]} \\
\mathrm{t}_{\mathrm{R}}(\mathrm{min}) \\
\text { Mixture }\end{array}$ & $\begin{array}{c}{[\mathrm{BPY}]} \\
\mathrm{t}_{\mathrm{R}}(\mathrm{min}) \\
\text { Individual }\end{array}$ & $\begin{array}{c}\text { [HOHMIM] } \\
\mathrm{t}_{\mathrm{R}}(\mathrm{min}) \\
\text { Mixture }\end{array}$ & $\begin{array}{c}\text { [HOEMIM] } \\
\mathrm{t}_{\mathrm{R}}(\mathrm{min}) \\
\text { Individual }\end{array}$ & $\begin{array}{c}{[\mathrm{N} 1888]} \\
\mathrm{t}_{\mathrm{R}}(\mathrm{min}) \\
\text { Mixture }\end{array}$ & $\begin{array}{c}\text { [N1888] } \\
\mathrm{t}_{\mathrm{R}}(\min ) \\
\text { Individu } \\
\text { al }\end{array}$ \\
\hline 1 & 1 & C6 & 0.098 & 0.098 & 0.098 & 0.098 & 0.154 & 0.120 \\
\hline 2 & 2 & C7 & 0.101 & 0.123 & 0.113 & 0.113 & 0.210 & 0.153 \\
\hline 3 & 3 & C8 & 0.157 & 0.156 & 0.131 & 0.131 & 0.230 & 0.230 \\
\hline 4 & 4 & C9 & 0.216 & 0.215 & 0.161 & 0.161 & 0.350 & 0.358 \\
\hline 5 & 5 & C10 & 0.305 & 0.303 & 0.215 & 0.216 & 0.525 & 0.525 \\
\hline 6 & 6 & C11 & 0.418 & 0.416 & 0.294 & 0.296 & 0.713 & 0.713 \\
\hline 7 & 7 & $\mathrm{C} 12$ & 0.545 & 0.544 & 0.394 & 0.395 & 0.913 & 0.913 \\
\hline 8 & 8 & C13 & 0.680 & 0.680 & 0.506 & 0.508 & 0.125 & 1.124 \\
\hline 9 & 9 & C14 & 0.822 & 0.822 & 0.625 & 0.630 & 1.341 & 1.342 \\
\hline 10 & 10 & C15 & 0.968 & 0.969 & 0.749 & 0.756 & 1.561 & 1.563 \\
\hline 11 & 11 & C16 & 1.116 & 1.118 & 0.878 & 0.889 & 1.784 & 1.785 \\
\hline 12 & 12 & C17 & 1.268 & 1.270 & 1.012 & 1.025 & 2.005 & 2.007 \\
\hline 13 & 13 & C18 & 1.419 & 1.424 & 1.149 & 1.164 & 2.226 & 2.229 \\
\hline 14 & 14 & C19 & 1.572 & 1.578 & 1.288 & 1.305 & 2.446 & 2.449 \\
\hline 15 & 15 & $\mathrm{C} 20$ & 1.724 & 1.731 & 1.427 & 1.447 & 2.664 & 2.668 \\
\hline 16 & 16 & $\mathrm{C} 21$ & 1.873 & 1.883 & 1.572 & 1.590 & 2.879 & 2.885 \\
\hline 17 & 17 & $\mathrm{C} 22$ & 2.018 & 2.033 & 1.708 & 1.731 & 3.092 & 3.100 \\
\hline 18 & 18 & $\mathrm{C} 23$ & 2.166 & 2.182 & 1.849 & 1.871 & 3.307 & 3.315 \\
\hline 19 & 19 & $\mathrm{C} 24$ & 2.310 & 2.329 & 1.987 & 2.013 & 3.541 & 3.549 \\
\hline 20 & 20 & $\mathrm{C} 25$ & 2.454 & 2.471 & 2.124 & 2.153 & 3.825 & 3.832 \\
\hline 21 & 21 & $\mathrm{C} 26$ & 2.594 & 2.613 & 2.263 & 2.292 & 4.190 & 4.196 \\
\hline 22 & 22 & $\mathrm{C} 27$ & 2.730 & 2.752 & 2.402 & 2.433 & 4.677 & 4.679 \\
\hline 23 & 23 & $\mathrm{C} 28$ & 2.876 & 2.890 & 2.540 & 2.570 & 5.330 & 5.334 \\
\hline 24 & 24 & $\mathrm{C} 29$ & 3.002 & 3.029 & - & - & - & 6.151 \\
\hline 25 & 25 & С 30 & - & - & - & - & - & 7.395 \\
\hline 26 & 1 & Benzene & 0.241 & 0.236 & 0.161 & 0.160 & 0.210 & 0.200 \\
\hline 27 & 2 & Pentanone & 0.480 & 0.487 & 0.364 & 0.363 & 0.478 & 0.450 \\
\hline 28 & 3 & Nitropropane & 0.745 & 0.715 & 0.556 & 0.560 & 0.525 & 0.535 \\
\hline 29 & 4 & Butanol & 0.651 & 0.652 & 0.441 & 0.427 & 0.657 & 0.601 \\
\hline 30 & 5 & Pyridine & 1.724 & 1.746 & 1.849 & 1.835 & 0.857 & 0.835 \\
\hline- & 1 & Heptane & - & 0.108 & - & 0.103 & - & 0.155 \\
\hline- & 2 & Octane & - & 0.126 & - & 0.129 & - & 0.229 \\
\hline- & 3 & Nonane & - & 0.166 & - & 0.160 & - & 0.359 \\
\hline- & 4 & Benzene & - & 0.238 & - & 0.160 & - & 0.200 \\
\hline 31 & 5 & Toluene & 0.371 & 0.365 & 0.215 & 0.217 & 0.341 & 0.321 \\
\hline 32 & 6 & Ethylbenzene & 0.480 & 0.481 & 0.271 & 0.279 & 0.478 & 0.461 \\
\hline 33 & 7 & P-Xylene & 0.525 & 0.528 & 0.294 & 0.305 & 0.499 & 0.484 \\
\hline 34 & 8 & m-Xylene & 0.525 & 0.528 & 0.294 & 0.305 & 0.506 & 0.492 \\
\hline 35 & 9 & o-Xylene & 0.604 & 0.602 & 0.350 & 0.360 & 0.572 & 0.553 \\
\hline 36 & 10 & Isobutylbenzene & 0.651 & 0.663 & 0.394 & 0.385 & 0.737 & 0.726 \\
\hline 37 & 11 & Styrene & 0.710 & 0.704 & 0.441 & 0.452 & 0.657 & 0.621 \\
\hline 38 & 12 & Butylbenzene & 0.765 & 0.775 & 0.471 & 0.466 & 0.857 & 0.845 \\
\hline 39 & 13 & 1,2-Dichlorobenzene & 0.905 & 0.897 & 0.556 & 0.569 & 0.957 & 0.933 \\
\hline 40 & 14 & 2,5-Dichlorotoluene & 0.968 & 0.960 & 0.584 & 0.597 & 1.083 & 1.057 \\
\hline 41 & 15 & $1,2,4$ Trichlorobenzene & 1.076 & 1.069 & 0.675 & 0.695 & 1.228 & 1.203 \\
\hline 42 & 16 & Benzyl chloride & 1.116 & 1.111 & 0.780 & 0.792 & 0.957 & 0.933 \\
\hline 43 & 17 & Naphthalene & 1.724 & 1.719 & 1.231 & 1.245 & 1.561 & 1.513 \\
\hline 44 & 18 & 2-Nitrotoluene & 1.797 & 1.792 & 1.393 & 1.418 & 1.642 & 1.600 \\
\hline 45 & 19 & 3-Nitrotoluene & 1.905 & 1.895 & 1.480 & 1.511 & 1.784 & 1.746 \\
\hline 46 & 20 & 4-Nitrotoluene & 2.018 & 1.999 & 1.572 & 1.609 & 1.891 & 1.838 \\
\hline
\end{tabular}


Table S3: Resolution of 20 chemical compounds

\begin{tabular}{|c|c|c|c|c|}
\hline $\begin{array}{l}\text { number } \\
\text { of peak }\end{array}$ & Compound & $\begin{array}{l}{[\mathrm{BPY}]} \\
\text { resolution }\end{array}$ & $\begin{array}{l}\text { [HOEMIM] } \\
\text { resolution }\end{array}$ & $\begin{array}{c}{[\mathrm{N} 1888]} \\
\text { resolution }\end{array}$ \\
\hline 2 & Octane & 1.76 & 1.49 & 3.56 \\
\hline 3 & Nonane & 2.56 & 2.16 & 2.12 \\
\hline 4 & Benzene & 4.7 & 2.16 & 5.4 \\
\hline 5 & Toluene & 9.9 & 4.69 & 2.12 \\
\hline 6 & Ethylbenzene & 7.7 & 3.48 & 5.41 \\
\hline 7 & P-Xylene & 2.2 & 1.17 & 1.36 \\
\hline 8 & m-Xylene & - & - & - \\
\hline 9 & o-Xylene & 3.39 & 2.71 & 2.25 \\
\hline 10 & Isobutylbenzene & 3.7 & 1.46 & 2.52 \\
\hline 11 & Styrene & 1.88 & 3.11 & 4.21 \\
\hline 12 & Butylbenzene & 4.4 & 0.88 & 4.71 \\
\hline 13 & $\begin{array}{c}1,2- \\
\text { Dichlorobenzene }\end{array}$ & 5.5 & 4.16 & 2.66 \\
\hline 14 & $\begin{array}{c}2,5- \\
\text { Dichlorotoluene }\end{array}$ & 3.5 & 1.65 & 4.25 \\
\hline 15 & $\begin{array}{c}1,2,4- \\
\text { Trichlorobenzene }\end{array}$ & 4.9 & 4.99 & 4.93 \\
\hline 16 & Benzyl chloride & 1.74 & 4.21 & 2.66 \\
\hline 17 & Naphthalene & 22.6 & 18 & 8.8 \\
\hline 18 & 2-Nitrotoluene & 2.28 & 5.3 & 2.15 \\
\hline 19 & 3-Nitrotoluene & 3.04 & 2.52 & 3.34 \\
\hline 20 & 4-Nitrotoluene & 2.9 & 2.48 & 2.03 \\
\hline
\end{tabular}

Table S4: Isothermal retention times of polar probes.

\begin{tabular}{|c|c|c|c|}
\hline Compound & {$[\mathrm{BPY}] \mathrm{t}_{\mathrm{R}}(\mathrm{min})$} & {$[\mathrm{HOEMIM}] \mathrm{t}_{\mathrm{R}}(\mathrm{min})$} & {$[\mathrm{N} 1888] \mathrm{t}_{\mathrm{R}}(\mathrm{min})$} \\
\hline Benzene & 0.121 & 0.115 & 0.123 \\
\hline Pentanone & 0.159 & 0.138 & 0.150 \\
\hline Nitropropane & 0.229 & 0.178 & 0.177 \\
\hline Butanol & 0.181 & 0.143 & 0.186 \\
\hline Pyridine & 0.468 & 0.486 & 0.230 \\
\hline
\end{tabular}


Table S5: Selectivity Index of ionic liquid stationary phases.

\begin{tabular}{|c|c|c|c|}
\hline Compound & $I^{*}[\mathrm{BPY}]$ & $I^{*}[$ HOEMIM] & $I^{*}[\mathrm{~N} 1888]$ \\
\hline Benzene & 138.3 & 88.8 & 114.3 \\
\hline Pentanone & 414.7 & 226.3 & 265.3 \\
\hline Nitropropane & 654.2 & 471.2 & 359.6 \\
\hline Butanol & 607.9 & 356.4 & 497.9 \\
\hline Pyridine & 1055.8 & 1052.4 & 564 \\
\hline$\Sigma I^{*}$ & 2870.9 & 2195.1 & 1801.1 \\
\hline
\end{tabular}

Thickness calculation of the IL stationary phases. As explained in the coating method, the IL solution filled the entire column. The thickness can be estimated based on the concentration of solution, surface area of column and density of ILs. First the empty volume inside of the channel is required.

$\mathrm{V}_{\mathrm{IL} 0}=\mathrm{V}_{\mathrm{R}}-\mathrm{V}_{\mathrm{P}}$

VIL is the volume of IL that is filled inside of the empty space between pillars in column. $\mathrm{V}_{\mathrm{R}}$ is the volume of column without pillars. $\mathrm{Vp}$ is the volume of the pillars. Based on the channel width of $190 \mathrm{um}$ and the height of $240 \mu \mathrm{m}$, the total length of $1 \mathrm{~m}$, and pillar diameter of $16 \mu \mathrm{m}, \mathrm{V}_{\mathrm{IL} 0}$ was obtained as $45 \mu \mathrm{l}$. We also recorded the coating process. The video records showing that the syringe was emptied for about the same amount to fill the column with the phase.

We used nitrogen flow for the drying step. We need to take account the amount of solution volume that was removed.

$\mathrm{V}_{\mathrm{ILf}}=\mathrm{V}_{\mathrm{IL} 0}-\mathrm{V}_{\mathrm{ILd}}$

$\mathrm{V}_{\text {ILd }}$ is the volume of the IL solution that pulled out during nitrogen drying step. $\mathrm{V}_{\text {ILf }}$ is the final remaining solution after drying that creates an estimate of the volume of the remainder of the stationary phase.

Our video records show after $1 \mathrm{~min}, 10 \mu \mathrm{l}$ of the bulk solution comes out from the column. That means that roughly about $35 \mu 1$ remains in the channel. 
Using the concentrations of ILs, the weight of the ionic liquid inside the column can be calculated. Then, we can obtain the estimated thickness of the stationary phase using the surface area of the column (Table 1).

$\left(\mathrm{C} \times \mathrm{V}_{\text {ILf }}\right) / \mathrm{D}=\mathrm{S} \times \mathrm{d}_{\mathrm{f}}$

$\mathrm{C}$ is the concentration of the IL solution, D is the density of IL, S is the surface area of column containing the walls of channels and surface of the pillars, and $d_{f}$ is the thickness of the stationary phase. The calculated amount of the column surface area is $17 \mathrm{~cm}^{2}$. Using these numbers, the calculated thickness for the IL1 phase becomes around $200 \mathrm{~nm}$, which is in good agreement with the measured value of $220 \mathrm{~nm}$ obtained from the SEM image. Using the same methodology, we estimated the thickness of the IL2 and IL3 phases to be around $190 \mathrm{~nm}$ and $26 \mathrm{~nm}$, respectively.

Table S6: parameters for IL thickness calculation

\begin{tabular}{|l|l|l|l|l|l|}
\hline IL name & C $(\mathrm{mg} / \mathrm{ml})$ & $\mathrm{D}(\mathrm{gr} / \mathrm{ml})$ & Weight $(\mathrm{mg})$ & $\mathrm{S} \times \mathrm{d}_{\mathrm{f}}(\mu \mathrm{l})$ & $\mathrm{d}_{\mathrm{f}}(\mathrm{nm})$ \\
\hline IL1 & 15 & 1.45 & 0.495 & 0.34 & 204 \\
\hline IL2 & 15 & 1.57 & 0.495 & 0.32 & 192 \\
\hline IL3 & 1.5 & 1.15 & 0.0495 & 0.043 & 26 \\
\hline
\end{tabular}


Table S7: Part catalog number of chemicals

\begin{tabular}{|l|l|}
\hline Chemical & Part catalog number \\
\hline$\left[\right.$ BPY] $\left[\mathrm{NTf}_{2}\right]$ & $\mathrm{IL}-0213-\mathrm{HP}$ \\
\hline$[\mathrm{HOEMIM}]\left[\mathrm{NTf}_{2}\right]$ & $\mathrm{IL}-0194-\mathrm{HP}$ \\
\hline$[\mathrm{N} 1888]\left[\mathrm{NTf}_{2}\right]$ & $\mathrm{IL}-0017-\mathrm{HP}$ \\
\hline Silicon wafer & 589 \\
\hline Borofloat wafer & 1837 \\
\hline Fused silica capillary tubes & $106815-0021$ \\
\hline Acetone & 650501 \\
\hline naphthalene & 184500 \\
\hline heptane & 34873 \\
\hline octane & 296988 \\
\hline nonane & 296821 \\
\hline benzene & 270709 \\
\hline toluene & 179418 \\
\hline ethylbenzene & 296848 \\
\hline p-Xylene & 296333 \\
\hline m-Xylene & 296325 \\
\hline o-Xylene & 95662 \\
\hline isobutylbenzene & 113166 \\
\hline styrene & 45993 \\
\hline butylbenzene & $\mathrm{B} 90203$ \\
\hline 1,2-Dichlorobenzene & 270598 \\
\hline 2,5-Dichlorotoluene & $\mathrm{D} 75955$ \\
\hline 1,2,4-Trichlorobenzene & 256412 \\
\hline benzyl chloride & 8018090 \\
\hline 2-nitrotoluene & 438804 \\
\hline 3-nitrotoluene & $\mathrm{N} 27314$ \\
\hline 4-nitrotoluene & $\mathrm{N} 27322$ \\
\hline butanol & 281549 \\
\hline nitropropane & $\mathrm{N} 22851$ \\
\hline pyridine & 270970 \\
\hline Pentanone & 471194 \\
\hline C7-C30 saturated alkanes & $49451-\mathrm{U}$ \\
\hline Helium & $\mathrm{HE} \mathrm{UHP300}$ \\
\hline nitrogen & $\mathrm{NI} \mathrm{UHP300}$ \\
\hline air & $\mathrm{HIOH} 300$ \\
\hline hydrogen & \\
\hline
\end{tabular}


References.

(1) Shakeel, H.; Rice, G. W.; Agah, M. Sens. Actuators B: Chem. 2014, 203, 641-646.

(2) Evans, M.; Haken, J. J. Chromatogr. A 1987, 406, 105-115.

(3) Lenca, N.; Poole, C. F. J. Chromatogr. A 2017, 1525, 138-144.

(4) Rajkó, R.; Körtvélyesi, T.; Sebők-Nagy, K.; Görgényi, M. Anal. Chim. Acta 2005, $554,163-171$. 